\section{Storm brewing over Toshiba's illegal exports}

\section{- Company president resigns over ban - Soviet 'silent submarine' theory}

Washington \& Tokyo

US ANGER over the illegal export of advanced milling machinery to the Soviet Union by a Japanese and a Norwegian company continues to mount some two months after the incident first became public.

Last week, a Senate trade bill was amended so as to ban for between two and five years the import into the United States of products made by the two companies involved - Toshiba Corporation of Japan and Kongsberg Vaapenfabrikk of Norway. Within hours, both the chairman and the president of Toshiba had resigned their posts. The Senate bill, as amended, would seek to recover damages from the two companies.

The milling machines may have enabled the Soviet Union to build submarine propellors whose noise emission is a minimum and which are therefore relatively immune from US listening equipment. US sources say that millions of dollars may now have to be spent on the improvement of listening equipment.

The illegal deal was initiated in 1980 , when a Soviet trade organization persuaded Toshiba Machine Company, a majority-owned subsidiary of Toshiba Corporation, to provide automated propellor manufacturing equipment. To avoid attracting attention to the sale, Toshiba Machine insisted on using a standard export broker and enlisting the aid of the Norwegian company. Under the terms of a contract signed in Moscow in 1981, Toshiba agreed to supply four milling machines and Kongsberg Vaapenfabrikk the associated computers and software.

It seems agreed that the companies well knew that export of the machines was prohibited under regulations of the intergovernmental coordinating committee on trade in sensitive equipment (COCOM). False documents were prepared to conceal the true nature of the equipment and which named a civilian end user. The machines were delivered to a Soviet Navy propellor production facility in Leningrad; installation was completed in 1984.

The US Department of Defense says that, in 1986, its underwater sonar detectors began to pick up silent-propellor Soviet submarines not detected by passive listening devices. The illegal sale of the equipment was first discovered by the United States in the subsequent investigation of improvement of Soviet propellor technology. It has since emerged that
Japan's Ministry of International Trade and Industry (MITI) had heard of the deal at an earlier stage, when a former employee of a Japanese company that had acted as an intermediary went to officials at COCOM's Paris headquarters. But MITI failed to conduct a full investigation.

The exported machinery is capable of milling extremely smooth complex surfaces on very large propellors, but it has not been proven that the new Soviet propellors were actually produced on the illegally exported machines. Japanese sources point out that the leak of information on submarine detector equipment by a US spy ring must have been equally important in helping build submarines the United States would find hard to detect.

Japan's Prime Minister Yasuhiro Nakasone has tried to make amends by offering to help the United States to develop antisubmarine technology. But this possibility, brought up during the recent visit of Defense Secretary Caspar Weinberger to Tokyo and to be followed up by a visit from US experts, has not been seen as sufficient in the US Senate. Nor has the Japanese government's ban on Toshiba exports to the Soviet Union for the year ahead, which was referred to by Senator Jake Garn (Republican, Utah) as a "slap with a wet noodle".

The resignation of the two senior officials of the Toshiba Corporation was accompanied by public apologies for "straining US-Japan relations" and for the "consequences of Toshiba Machine's behaviour for the security of the Western world". Despite the nobility of their public act, however, the real feelings of the company officials may be somewhat different. Toshiba officials continue to stress that the parent company held only 50.8 per cent of Toshiba Machine's stock and, as is usual in Japan, did not monitor in detail what went on in the subsidiary.

To punish the parent for a grown-up son's behaviour is seen as unfair. A US accounting company is to examine Toshiba Corp.'s books to certify that it knew nothing of the illegal sale.

This action, and the resignations, are unlikely to affect the demands for action in Washington. Although an attempt to match the Senate amendment with an amendment to a bill in the House of Representatives failed on a point of order, legislation will be considered in coming weeks.

Alun Anderson \& David Swinbanks
Superconductor success for Japanese

Tokyo

JAPAN and the United States are racing neck and neck in the development of hightemperature superconductors. It is less than two months since IBM scientists announced success in growing a singlecrystal thin film with a current-carrying capacity greater than $100,000 \mathrm{~A} \mathrm{~cm}^{-2}$ at the temperature of liquid nitrogen (Nature 327,$89 ;$ 1987). Researchers at Nippon Telephone and Telegraph (NTT) have now topped that record by a factor of more than ten by using essentially the same technique.

One of the major barriers to development of electronic devices from the new superconductors is the low currentcarrying capacity of the oxide ceramics. But this barrier is fast being eroded.

Last week (30 June) NTT announced the development of a thin film of yttrium barium-copper oxide with a maximum critical current density of 1.8 million $A$ $\mathrm{cm}^{-2}$ at $77.3 \mathrm{~K}$. The single-crystal film was prepared by $\mathrm{RF}$ magnetron sputtering on a monocrystal $\mathrm{Sr}^{\mathrm{TiO}} \mathrm{O}_{3}$ substrate.

As in the case of the IBM results, the critical current is dependent on direction in the crystal: the maximum current was observed parallel to the $a / b$ plane of the copper oxide, while in the $c$-axis direction, parallel to the surface of the film, the critical current density was two orders of magnitude lower at $10,000 \mathrm{~A} \mathrm{~cm}^{-2}$.

Almost simultaneously with the NTT announcement, Sumitomo Electric Industries Ltd, a major cable manufacturer, claimed to have developed a bulk ceramic which is superconducting at room temperature. The ceramic, composed of yttrium-barium-copper oxide and a "secret ingredient", was compressed into five 3-mm-thick disks (diameter $7 \mathrm{~mm}$ ) which, depending on the disk, showed zero resistance at temperatures ranging from 77 to $300 \mathrm{~K}$. One of the disks (unspecified) "seemed" to show the Meissner effect, according to Sumitomo. But the superconducting properties in the material were unstable and only lasted from one to seven days. Unequivocal evidence of room-temperature superconductivity has yet to be found. David Swinbanks

\section{Nature's Tokyo print}

From this week's issue, Nature will be printed regularly in Tokyo, for distribution in Japan and elsewhere in East Asia. Editorially, the Tokyo edition of Nature will be identical with those printed in Britain and the United States, although the advertisements may differ. For an explangtion of the reasons for this development, see page 97. 